\title{
Майбуття як філософсько-футурологічна проблема
}

\author{
Людмила Опейда - \\ кандидат філософських наук, \\ дочент кафедри всесвітньої \\ історії та філософії, Волинський \\ національний університет \\ імені Лесі Украӥнки, Луиььк, \\ Украӥна
}

\author{
Liudmyla Opeida - \\ PhD in Philosophy, Associate \\ Professor, Department of World \\ History and Philosophy, Lesya \\ Ukrainka Volyn National \\ University, Lutsk, Ukraine \\ E-mail: opeida@gmail.com \\ ORCID: https://orcid.org/0000- \\ 0003-3914-5250
}

\author{
Артур Опейда - \\ аспірант кафедри всесвітньої \\ історії та філософії, Волинський \\ національний університет \\ імені Лесі Украӥнки, Луцьк, \\ Україна \\ Artur Opeida - \\ PhD student in Philosophy, \\ Department of World History and \\ Philosophy, Lesya Ukrainka Volyn \\ National University, Lutsk, Ukraine \\ E-mail: arturopeida@gmail.com \\ ORCID: https://orcid.org/0000- \\ 0002-8950-0129
}

У статті здійснено аналіз проблеми прогнозування та моделювання майбутнього. Конкретизовано поняття «майбуття» та «прийдешнє» порівняно 3 «теперішнім» і «минулим». Акцентовано увагу на тому, що методологічною основою футурологічних досліджень завжди була філософія з їі світоглядно-прогностичною функцією. Для ефективнішого розв'язання проблеми потрібне поєднання обох підходів. Більше того, прогнозування майбутнього вимагає міждисциплінарних досліджень.

Аналіз сучасних парадигм засвідчив, що важливо враховувати їхні позитивні сторони в намаганні накреслити траєкторію майбуття, водночас не можна нехтувати також можливими ризиками. Зрештою, сучасне суспільство настільки стрімко розвивається, що треба враховувати сукупність чинників економічного, екологічного, соціального, політичного характеру. Останні все більше набувають глобальних масштабів. Тому важливо в розробці ефективних моделей майбутнього враховувати ті тенденції, які досліджуються сучасною глобалістикою. Лише завдяки системному та комплексному підходам вдасться створити потужну модель майбутнього розвитку людської цивілізації.

DOI: $10.29038 / 2306-3971-2020-$

02-13-17

Reseived: September, 2020

$1^{\text {st }}$ Revision: October, 2020

Accepted: November, 2020

Ключові слова: майбуття, прийдешнє, теперішнє, минуле, час, сучасність, співучасність.

Opeida Liudmyla, Opeida Artur. The Future as a Philosophical and Futurological Problem. The article analyzes the problem of prognostication and modeling of the future. The concepts «future» and «futurity» in comparison with «present» and «past» are concretized. The emphasis is placed on the fact that philosophy with its worldview and prognostic function has always been the methodological basis of the futurological research. A combination of both 
approaches is needed to solve the problem more effectively. Moreover, the future prognostication requires interdisciplinary research.

The analysis of modern paradigms has shown that it is important to take into account their positive aspects in an attempt to outline the trajectory of the future, at the same time, possible risks should not be neglected. Modern society is developing so rapidly that there is a necessity to take into account a set of economic, environmental, social, political factors. The latter are becoming increasingly global. Consequently, in the development of the effective models of the future it is important to take into account the trends that are studied by modern globalistics.

Only through systematic and comprehensive approaches it will be possible to create a powerful model for the future development of human civilization.

Key words: future, futurity, present, past, time, modernity, complicity.

Опейда Людмила, Опейда Артур. Будущее как философско-футурологическая проблема. В статье анализируется проблема прогнозирования и моделирования будущего. Конкретизируется понятие «будущее» по сравнению с «настоящим» и «прошлым». Акцентируется внимание на том, что методологической основой футурологических исследований всегда была философия с ее мировоззренческо-прогностической функцией. Для эффективного решения проблемы необходимо объединение обоих подходов. Более того, прогнозирование будущего требует междисциплинарных исследований.

Анализ современных парадигм показал, что важно учитывать их позитивные стороны в намерениях начертить траекторию будущего, в то же время не стоит игнорировать возможные риски. Современное общество настолько стремительно развивается, что есть необходимость учитывать совокупность факторов экономического, экологического, социального, политического характера. Последние все более глобализируются. Поэтому важно в разработке эффективных моделей будущего учитывать тенденции, исследуемые современной глобалистикой. Только благодаря системному и комплексному подходам, можем сформировать полноценную модель будущего развития человеческой цивилизации.

Ключевые слова: будущее, наступающее, настоящее, прошлое, время, современность, соучастие.

Постановка наукової проблеми та її значення. Людину завжди цікавило майбутнє й особливо на зламі століть, тисячоліть. Початок XXI ст. актуалізує та активізує пошуки майбуття. Більше того, перед сучасниками відкривається величезна палітра шляхів-можливостей для реалізації різноманітних варіантів розвитку людської цивілізації. Питання полягає в тому, щоб кожен зумів віднайти ці шляхи й, зібравши всі елементи власної особистості, здійснив важливий та відповідальний вибір на користь і собі, i суспільству, і людству. Насправді, це не так складно, як видається на перший погляд. Адже сучасна людина живе в час інформаційного суспільства, стрімкого розвитку інноваційних технологій, де варто якнайшвидше зорієнтуватися та зробити крок назустріч майбутньому.

Відомо, що й наука така існує - футурологія (від лат. futurum - майбутнє і грец. $\lambda$ о́ «Футурологія - це здатність сприймати дійсність по-новому, уміти визнавати те, що життя змінюється, та пробувати пояснювати ці зміни» (Горбатенко, 2017, с. 40). Методологічною основою цієї науки завжди була філософія 3 iі світоглядно-прогностичною функцією. Тому в пошуках відповідей на задекларовані вище запити потрібно поринути в царину цих дисциплін і не тільки. Зауважимо, що пошуки мають бути в основному міждисциплінарними.

Аналіз останніх досліджень проблеми засвідчив, що нею переймалися представники різних галузей знання, як от: Р. Арон, М. Бердяєв, З. Бжезінський, В. Вернадський, Д. Вілсон, Б. Гаврилишин, С. Гантінгтон, Е. Ільєнков, М. Кайку, С. Кримський, А. Печчеї, П. Сорокін, Е. Тофлер, С. Франк, Е. Фромм, Ф. Фукуяма, О. Шпенглер, Ю. Щербак й інші.

Так, на думку С. Франка, майбутнє як цілісний об’єкт не вивчає жодна наука, окрім філософії. С. Кримський зауважує, що майбутнє не приходить подібно до весни, воно проєктується й постає пріоритетною життєвою цінністю. Представники Римського клубу, проаналізувавши можливі сценарії поступу людства, акцентують увагу на необхідності розкриття здібностей кожної особистості та іiі відповідальності за майбутне.

Відомий американський учений Мічіо Кайку розглядає майбутнє 3 позицій науки. Він стверджує, що «ключ до розуміння майбутнього - це фундаментальні закони природи...» й «без науковця немає майбутнього» (Кайку, 2013, с. 20-21). «Справжня сила науки полягає в тому, що вона дає нам більше можливостей і більше влади - водночас залишаючи вибір» (Кайку, 2013, с. 393). Так оцінює вчений 
творчо-інноваційний потенціал людства. Завдяки науці формується «планетарна цивілізація». I це творення ми спостерігаємо ледве не щоденно.

Відтак учений висловлює сподівання, що у XXI ст. «люди застосовуватимуть меч науки 3 мудрістю», тому й підкреслює завдання - знайти мудрість, яку він убачає у вмінні «визначити найважливіші питання сучасності, проаналізувати їх у багатьох різних ракурсах, а тоді вибрати те, що несе в собі якусь благородну мету і принципи» (Кайку, 2013, с. 394). Безперечно, такі завдання й запитання відносять нас до царини філософії як любові до мудрості.

Мета й завдання статті полягають у показі тих колізій та суперечностей, якими пронизаний шлях людини в пошуках омріяного майбуття. Від чого й від кого залежить наше майбутнє? Які фактори $є$ визначальними під час його прогнозування та моделювання?

Виклад основного матеріалу й обгрунтування отриманих результатів, на нашу думку, потрібно розпочати з аналізу ключового поняття дослідження, яким, безперечно, $\epsilon$ «майбутнє», «майбуття». Це те, що «має бути», що «відбудеться», «збудеться», станеться так чи інакше, із нашою чи без нашої участі, або з різним ступенем нашої участі й співучасті.

Етимологія слова «май-буття» відсилає до його складників «мати» та «бути», які вказують на продовження буття, його тривалість і водночас тривкість, пере-рвність, що від-бувається в момент граничного вибору буття, а отже, вибору можливостей, які у-безпечать та за-безпечать наше подальше існування (екзистенцію), тобто перетворять можливості в дійсність і т. ін. Такі зміни-пере-творення, у людському вимірі - трансцендування, - постійні й безкінечні. Тому справедливо звучать слова, що людина - це істота, котра трансцендує. По-іншому, людина - у можливості, а отже - у май-бутті.

Закономірно, що людський світ культури й цивілізації також рухається подібним шляхом (найчастіше його зображують у вигляді спіралі). Останнім часом помічаємо, що швидкості на цьому шляху стрімко зростають і зміни все виразніші й незворотні. Наприклад, скорочення часових інтервалів між науковими відкриттями-інноваціями.

Початок XXI ст. засвідчує та виносить на поверхню допоки «невідомі» людству проблеми (чого лише варта пандемія COVID-19). Су-часна людина просто не встигає їх розв'язувати. Можливо, тому, що підходить до прийняття рішень однобоко, частково, фрагментарно, не зовсім усвідомлюючи масштабність наслідків наявних проблем.

Та благо, що на допомогу приходить сучасна наука, філософія, футурологія, зрештою глобалістика, які просто зобов'язані при-відкрити найближче майбутне людської цивілізації, та, виявивши новітні тенденції, скоригувати й спроєктувати останнє.

Так, філософія, розглядаючи проблему майбуття, відносить нас до глибинної онтологічної проблематики, де часовість і буттєвість розглядаються як єдине ціле. Більше того, саме в людському бутті тісно переплітаються часові виміри минулого, теперішнього та майбутнього.

Х. Арендт стверджує, що «з погляду людини, яка завжди живе в інтервалі між минулим та майбутнім, час не $\epsilon$ чимось суцільним, таким собі потоком безперервних послідовностей, він уривається посередині, в тій точці», де зіштовхуються нескінченне минуле й нескінченне майбутнє (Арендт, 2002, с. 15). Л. Гнатюк у книзі «Вступ до філософії теперішнього» зауважує, що майбутнє $є$ «тим самим теперішнім, яке є єдиним і яке не можна розкласти на частини» (Гнатюк, 1997, с. 307).

Загалом, проблема майбутнього трактується філософами в різних аспектах: в онтологічному, гносеологічному, соціально-філософському, етичному, про що свідчить наукова спадщина М. Бердясва, Л. Карсавіна, А. Тойнбі, С. Франка, О. Шпенглера, К. Ясперса та ін.

Потрібно зазначити, що багатьох дослідників усе більше цікавить праксеологічний аспект, пов'язаний із питанням творення майбуття.

Так, О. Шпенглер стверджує, що майбутнє треба виводити з того, що «може відбутися і, значить, відбудеться з безумовною неминучістю», та критично оцінювати те, «що не належить до внутрішніх можливостей епохи», щоб не витрачати «величезні обсяги розуму та сил ... на хибних шляхах» (Шпенглер, 1993, с.175). Науковець також наголошує на методологічній функції філософії в пізнанні майбутнього.

Отож, від проблеми майбутнього людям не сховатися, бо майбутнє «породжуємо ми й воно полягає в продовженні суттєвого...», тому «можна передбачити типовий смисл близького майбутнього, визначити наперед загальні риси прийдешньої епохи», а кожна «епоха не випадкова, їй 
притаманна стійка недвозначна внутрішня зв'язність» (Ортега-і-Гассет, 1991, с. 8). Тому майбутнє «вічна проблема», яка нині стає першочерговою в процесі розв'язання глобальних проблем людства.

М. Голянич у монографії «Футурологія. Філософія майбуття» пропонує таке визначення: «Майбутнє (майбуття) - це поняття, яке виражає можливості того наступного в наявному бутті, того, що з'явиться після фіксації сьогочасного стану якогось об'єкта в пізнавальній діяльності суб'єкта» (Голянич, 2017, с. 4). При цьому вчений наголошує на тісній взаємодії філософії з іiї прогностичною функцією та футурології, яку нині визначають як комплексну дисципліну, що «на основі суспільствознавчих і природничих наук досліджує й передбачає майбутнє» (Голянич, 2017, с. 4).

Не секрет, що на початку XXI ст. науковці все більше цікавляться питаннями про творення майбуття, акцентуючи увагу на практично-креативній функції футурології як філософії майбутнього. Іншими словами, сучасних учених цікавить алгоритм пере-творення, трансформації наявних можливостей у дійсність. Ключовим агентом такої корекційної креативності є сучасна (в-часна, своєчасна) людина, яка чітко усвідомлює відповідність поточному моменту, а отже, спроможна приймати оптимально-зважені рішення й брати на себе відповідальність за наступний крок знову та знову.

Постає питання, як стати сучасною людиною? I чи $€$ такі серед нас? Безперечно, вони поряд: знаючі, умілі, небайдужі, чесні, справедливі, відважні, людяні, тобто ті, котрі виробили в собі справжні буттєві цінності та продовжують їх продукувати, незважаючи ні на що, тим самим проєктуючи та корегуючи людське життя-буття. Адже, як відомо, антропний принцип ніхто не відміняв, як не відміняв принцип активності суб'єкта, принцип самоорганізації та самоуправління складних еволюціонуючих систем, зрештою - принцип цілісності людського буття.

Більше того, прогностична функція філософії майбутнього знайшла нині вираження в численних концепціях «постіндустріального», «технотронного», «інформаційного» суспільства, «соціокультурної еволюції», «третьої хвилі», «кінця історії», «зіткнення цивілізацій» і низки інших моделей майбутнього.

Проаналізувавши ці концепції, М. Голянич робить висновок, що дослідники, котрі «вивчають майбутнє в часовому вимірі, намагаються передбачити його на основі трактування лінійного продовження тенденцій минулого й теперішнього» (Голянич, 2017, с. 529). Тому, за критерієм оцінки характеру та спрямованості виявлених тенденцій серед футурологів учений виділяє групи «позитивістів»- «негативістів», «прогресистів» «регресистів». Філософ також звертає увагу на песимістичні висновки представників «футурологічного агностицизму» та прихильників фаталістиного тлумачення майбутнього, а також на численні «теорії майбутнього суспільства» (Голянич, 2017, с. 529).

Автор зауважує, що сьогодні все більше мислителів звертають увагу на новітні тенденції в міжнародних відносинах, перспективи збереження миру та життя на Землі. Звідси - «передбачення стосовно економічної і політичної сфер суспільства, трансформації сім'ї, соціальних відносин та окремих спільнот, майбутнього демократії, науки, техніки, інформаційних технологій» ... «найчисленнішою групою $є$ автори різних концепцій інформаційного суспільства та його трансформації в умовах глобалізації світу» (Голянич, 2017, с. 530).

Потрібно зазначити, що «розробка образу бажаного майбутнього не буде плідною без критичного погляду на теперішне і минуле та врахування існуючої динаміки розвитку». 3 іншого боку, «розмови про бажане майбутнє без намагань втілити його у життя також видаються малопродуктивними» (Сухорольський, Сухорольська, 2018, с. 122).

У контексті глобалізаційних змін розглядають учені й майбутнє України. Так, ідеї гуманістичного характеру висловлюють М. Амосов, В. Вернадський, Б. Гаврилишин, А. Толстоухов, М. Шлемкевич, Ю. Щербак та ін.

Відомо, що Ю. Щербак вирізняється «концептуальністю поглядів на майбутнє України, світу, людської цивілізації й людини як біосоціальної духовної істоти» (Голянич, 2017, с. 530). Зокрема, він прогнозує: щоб «віртуальна» Україна стала «реальною», треба буде працювати роками (Щербак, 2003, c. 307, 513). При цьому потрібно здолати моральну кризу, зневіру в державні та суспільні інститути, тому, як сподівається автор, до влади має прийти моральний авторитет, котрий «згуртує громадян, спраглих за правдою і честю» (Щербак, 2003, с. 521). Рушійною ж силою на цьому шляху має бути нове покоління (Щербак, 2003, с. 522). 
Мислитель також прогнозує, що, попри всі прорахунки, фактична «незворотність побудови нової Української держави відкриває перед українським народом нові, ще далеко не усвідомлені ні керівництвом, ні суспільством, перспективи» (Щербак, 2003, с. 456, 470).

Україна ще стоїть спиною до майбутнього, бо одні українці живуть ще ілюзіями й міфами минулого, а другі - не сприймають невизначеного сьогодення та втрачають віру в майбутнє. Тут Ю. Щербак категорично заявляє: «Або будемо сильною, могутньою нацією, яка здатна побороти всі негаразди, або зійдемо з історичної арени». Тому так важливо звернутися до проблем майбутнього (Щербак, 2003, с. 494, 495).

Із цією метою держава повинна більше дбати про розвиток науки, про розширення можливостей включення українських учених до сучасного глобального наукового процесу, до найперспективніших наукових досліджень. Важливо також залучати найяскравіших, які нестандартно думають, особистостей до планування майбутнього (Щербак, 2003, с. 502). Адже народжується нова спільнота й «людина всесвітня» (Homo globalis), «гряде глобальна інформаційна революція, що докорінно змінить світосприйняття, ментальність мільярдів людей, суспільні відносини і спосіб виробництва, породить нові етичні проблеми, про які можна сьогодні лише здогадуватись» (Щербак, 2003, с. 506). До таких міркувань автора, без сумніву, треба прислухатися, як і до власного сумління, мріючи про майбутнє.

Висновки та перспективи подальших досліджень. На нашу думку, звернення до потужного потенціалу комплексних філософсько-футурологічних концепцій неабияк сприятиме визначенню оптимальних шляхів подальшого поступу людства. Розширюючи можливості вивчення майбутнього, ми сприятимемо його творенню.

Перспективною видається також Тофлерова ідея «особистості майбутнього» з різними варіантами іiі інтерпретації, які відкривають ще один напрям досліджень - «соціологію майбутнього».

\section{Джерела та література}

1. Арендт, Х. (2002). Між минулим і майбутнім. Пер з англ. Київ: Дух і літера, 321 с.

2. Гнатюк, Л. В. (1997). Введение в философию настоящего. Киев: Киевское братство, 326 с.

3. Голянич, М. (2017). Футурологія. Філософія майбуття. Монографія. Івано-Франківськ: Вид-во «Лілея$\mathrm{HB} », 540 \mathrm{c}$.

4. Горбатенко, В. П. (2017). У пошуках майбутнього: до проблеми еволюції футурології як науки. Наукові прачі МАУП. Серія: Політичні науки, 52 (1), 35-48.

5. Кайку, М. (2013). Фізика майбутнього. Пер. з англ. Анжела Кам’янець. Львів: Літопис, 432 с.

6. Ортега-и-Гассет, Х. (1991). Что такое философия? Москва: Наука, 408 с.

7. Сухорольський, П. М., Сухорольська, І. Ю. (2018). Основні етапи розвитку футурології та ії завдання в умовах сучасного світу. Грані, 21(3), 116-123.

8. Шпенглер, О. (1993). Закат Европы. Очерки морфологии мировой истории. Пер. с нем., вст. сл. и примечания К. А. Свасьяна. Москва: Мысль, 663 с.

9. Щербак, Ю. (2003). Украӥна: ВИКЛИК і ВИБІР. Перспективи Украӥни в глобалізованому світі ХХІ сторіччя. Київ: Дух і Літера, 578 с.

\section{References}

1. Arendt, H. (2002). Between Past and Future. Transl. from English. Kyiv: Spirit and Letter, $321 \mathrm{p}$.

2. Hnatyuk, L. V. (1997). Introduction to the Philosophy of the Present. Kyiv: Kyiv Brotherhood, $326 \mathrm{p}$.

3. Golyanich, M. (2017). Futurology. Philosophy of the Future. Monograph. Ivano-Frankivsk: Publ. House «Lileya-NV», $540 \mathrm{p}$.

4. Gorbatenko, V. P. (2017). In Search of the Future: to the Problem of the Evolution of Futurology as a Science. IAPM Scientific Work. Political Science Section, 52 (1), 35-48.

5. Kaku, M. (2013). Physics of the Future. Transl. from English by A. Kamyanets. Lviv: Chronicle, 432 p.

6. Ortega y Gasset, J. (1991). What is Philosophy? Moscow: Science, 408 p.

7. Sukhorolskyi, P. M., Sukhorolska, I. Yu. (2018). Futures Studies: Main Stages of Development and Tasks in the Modern World. Grani. 21(3), 116-123. DOI: 10.15421/171847

8. Spengler, O. (1993). Sunset Europe. Essay of Morphology of World History. Transl. from German, Introduction and notes by K. A. Svasyan. Moscow: Thoughts, 663 p.

9. Scherbak, Y. (2003). Ukraine: Challenge and Choice. Prospects of Ukraine in the Globalized World of the XXI century. Kyiv: Spirit and Letter, 578 p. 